\title{
SELECTION OF OPTIMUM MAINTENANCE AND REHABILITATION STRATEGY FOR MULTILANE HIGHWAYS
}

\author{
Kunal Jain ${ }^{1}$, Sukhvir Singh Jain ${ }^{2}$, Mahipal Singh Chauhan ${ }^{3}$ \\ 1, 2 Department of Civil Engineering, Indian Institute of Technology Roorkee, Uttrakhand, India - 247667 \\ ${ }^{3}$ Department of Civil Engineering, Govind Ballabh Pant Engineering College, Pauri Garwal, India - \\ 246001
}

Received 15 September 2012; accepted 22 April 2013

\begin{abstract}
Pavements which are left to deteriorate without timely maintenance treatments are likely to require major rehabilitation and reconstruction much sooner than those which are properly maintained. In developing countries like India, where the traffic growth and axle loading is growing at logarithmic scale, deterioration of highways is very fast. This increased traffic demands for multilane highways with proper maintenance time to time. During the process of road network maintenance and rehabilitation, road authorities strive to select an optimum maintenance strategy from a number of alternatives. This selection may be obtained only through a realistic approach. An economically acceptable maintenance strategy may be selected among a number of maintenance alternatives. It can be done by calculating and comparing the various maintenance and rehabilitation $(M \& R)$ alternatives with the help of Highway Development and Management tool (HDM-4). This available technology and tool that makes implementing an effective pavement rehabilitation program feasible, is globally accepted. This paper specifically addresses flexible pavement, including the multilane highways from northern region of India. Study involves the data collection and selecting the optimum M\&R strategy by using programme analysis component of HDM-4 for selected road sections. It is expected that the information contained in this paper would be useful for developing optimum maintenance management strategy for multilane highways.
\end{abstract}

Keywords: maintenance and rehabilitation strategy, deterioration, Highway Development and Management tool (HDM-4).

\section{Introduction}

In the past, the pavements are maintained but not managed. The highway engineer based upon his experience used to dictate the maintenance and the rehabilitation techniques with little care given to life cycle costing and other management requirements, but in today's economic environment, there is a need of more systematic approach to determine the maintenance and rehabilitation techniques and the priorities. The pavement networks must be managed, not simply maintained. The pavement management system provides a systematic consistent method for selecting maintenance and rehabilitation techniques. It determines the priorities and the optimal time for the repair by predicting future pavement condition (Shahin, 2005). The proportion of paved road length in India is just below $50 \%$ and is much lower as compared to Japan, Malaysia and Republic of Korea as shown in

${ }^{1}$ Corresponding author: kjaindce@iitr.ernet.in 
Table 1. To overcome this, National Highways and Expressways are being constructed in India at a major scale. Hence, there is a need to maintain these roads with optimum maintenance strategies at appropriate time in view of the limited funds available. Pavement Management System (PMS) is a valuable tool that alerts the pavement manager to the critical point in a pavement's life cycle.

The cities and urban areas have witnessed phenomenal increase in population, number of vehicles and steep rise in industrial, commercial and residential activities. The National Highways and Expressways in India account for nearly $2 \%$ of total roads and are about 71 thousand $\mathrm{km}$ in length (MORT\&H, 2012). A large portion of our country resources is spent on maintenance and development of highways. This is a critical issue and cannot be overlooked. The direct saving in capital and maintenance costs and the indirect benefits to the road users in terms of improved comfort, safety and savings in vehicle operation can justify any large investment in maintenance and rehabilitation. The economic loss due to poor condition of roads is very high with over 400 lakh vehicles plying on the roads. Thus, importance of prioritization of road maintenance is high when availability of funds is low.

\section{Literature Review}

Maintenance and rehabilitation ( $M \& R$ ) requirements of roads depends upon the extent of damage and strengthening of the existing roads. The limited funds available should be used scientifically to have maximum benefit. For this, an investment strategy is needed to be developed to meet the requirements for the maintenance and rehabilitation of roads. The decision is to be made, at which sections, it is 'best' or 'optimal' to take the maintenance and rehabilitation within the available funds (Jain et al., 1996).The conventional practice of economic analysis of pavement strategies does not consider the differences in pavement performance levels among the alternatives analysed (Fwa and Sinha, 1991). SanchezSilva et al. (2005) employed a probabilistic

Table 1

Major Road Indicators across Selected Countries

\begin{tabular}{|c|c|c|c|c|c|}
\hline \multirow{2}{*}{ Country } & \multirow{2}{*}{$\begin{array}{c}\text { Road Density } \\
(\mathbf{k m} / \mathbf{s q} \mathbf{k m})\end{array}$} & $\begin{array}{c}\text { \% of Paved } \\
\text { Road }\end{array}$ & \multicolumn{3}{|c|}{ Road Length in Kilometre } \\
\cline { 5 - 6 } & & & Total & Motorways & $\begin{array}{c}\text { National } \\
\text { Highways }\end{array}$ \\
\hline Brazil & $0.20(2004)$ & N.A. & $1751868(2004)$ & 0 & $93071(5.31)$ \\
\hline China & $0.36(2007)$ & $44.10(2007)$ & $3583715(2007)$ & $45339(1.31)$ & $45289(1.31)$ \\
\hline France & $1.72(2007)$ & $100.00(2007)$ & $951125(2007)$ & $11010(1.16)$ & $9115(0.96)$ \\
\hline India & $1.25(2008)$ & $49.54(2008)$ & $4109592(2008)$ & 0 & $66754(1.62)$ \\
\hline Japan & $3.16(2007)$ & $79.29(2007)$ & $1196999(2007)$ & $7383(0.62)$ & $54347(4.54)$ \\
\hline Korea Republic & $1.03(2007)$ & $77.59(2007)$ & $102061(2007)$ & $3103(3.04)$ & $14225(13.94)$ \\
\hline Russian Federation & $0.05(2006)$ & $80.92(2006)$ & $933000(2006)$ & 0 & N.A. \\
\hline South Africa & $0.30(2001)$ & $17.30(2001)$ & $364131(2001)$ & $239(0.07)$ & $2887(0.79)$ \\
\hline United Kingdom & $1.72(2007)$ & $100.00(2007)$ & $420009(2007)$ & $3673(0.87)$ & $49009(11.67)$ \\
\hline United States of America & $0.68(2005)$ & $65.34(2005)$ & $6544257(2005)$ & $75435(1.15)$ & $270402(4.13)$ \\
\hline
\end{tabular}

Source: MORT\&H (2010) 
model for determining optimal design of flexible pavement that considers subsequent rehabilitation cost but not explicitly the physical effects of rehabilitations. Deshpande et al. (2008) proposed a reliability-based model that takes account of rehabilitation effects for yielding optimal pavement design and rehabilitation strategies. These authors used indices of fatigue damage for representing pavement performance without relating them to user costs. This shortcoming was addressed by Abaza (2002) and Abaza and Abu-Eisheh (2003) who proposed a life-cycle model of flexible pavements that considers road user cost in the optimization of maintenance strategy. Mamlouk et al. (2000) developed a project-level pavement management system for analyzing optimal pavement design and maintenance strategies (PDMSs). Jain et al. (2011) suggested a decision tree approach to find the optimal maintenance strategy. So, a strategy should be developed to consider the various level of pavement performance and uses the maintenance alternative accordingly.

\section{Selected Study Area}

The study area consists of one Expressway (Noida to Greater Noida) and National Highway (NH-24, Ghaziabad- Hapur). Expressway has been divided into five subsections and $\mathrm{NH}-24$ has been divided into 8 sub-sections. The sub-sections so divided are quite homogeneous within themselves as far as climatic and geometric conditions are considered but vary considerably from each other in traffic characteristics and pavement surface conditions. All the selected pavement sections have been assigned unique 'Section ID' and a 'Section Name' for ease in identification and for input to HDM-4, as shown in Table 2.

\section{Intervention Criteria for Maintenance of Primary Roads}

The main objective of a pavement maintenance management system is to provide a scientific tool to maintain roads at desired serviceability

\section{Table 2}

\section{Selected Pavement Sections}

\begin{tabular}{|c|c|c|c|c|c|}
\hline S.No. & Road Section & Section ID & Section Name & \begin{tabular}{|c|}
$\begin{array}{c}\text { Length } \\
(\mathbf{k m})\end{array}$ \\
\end{tabular} & $\begin{array}{c}\text { Width } \\
(\mathbf{m})\end{array}$ \\
\hline \multirow{5}{*}{1} & \multirow{5}{*}{$\begin{array}{l}\text { Expressway: Noida To } \\
\text { Greater Noida } \\
\text { (Total Length }=23.5 \mathrm{~km} \text { ) }\end{array}$} & NGN1 & Mahamaya flyover to Bus Stop Ch. 5.0 & 5.0 & 10.5 \\
\hline & & NGN2 & Bus Stop Ch. 5.0 to Advit Navis Business Park & 5.0 & 10.5 \\
\hline & & NGN3 & Advit Navis Business Park to Nr. Brick Kiln & 5.0 & 10.5 \\
\hline & & NGN4 & Brick Kiln to GN Sign Board & 5.0 & 10.5 \\
\hline & & NGN5 & GN Sign Board to GN Roundabout & 3.5 & 10.5 \\
\hline \multirow{8}{*}{2} & \multirow{8}{*}{$\begin{array}{l}\text { National Highway } 24: \\
\text { Ghaziabad to Hapur } \\
\text { (Total Length }=40.0 \mathrm{~km} \text { ) }\end{array}$} & NH-24-01 & Km Stone Delhi $11.0 \mathrm{~km}$ to $16.0 \mathrm{~km}$ & 5.0 & 7.0 \\
\hline & & $\mathrm{NH}-24-02$ & Km Stone Delhi $16.0 \mathrm{~km}$ to $21.0 \mathrm{~km}$ & 5.0 & 7.0 \\
\hline & & NH-24-03 & Km Stone Delhi $21.0 \mathrm{~km}$ to $26.0 \mathrm{~km}$ & 5.0 & 7.0 \\
\hline & & NH-24-04 & Km Stone Delhi $26.0 \mathrm{~km}$ to $31.0 \mathrm{~km}$ & 5.0 & 7.0 \\
\hline & & NH-24-05 & Km Stone Delhi $31.0 \mathrm{~km}$ to $36.0 \mathrm{~km}$ & 5.0 & 7.0 \\
\hline & & NH-24-06 & Km Stone Delhi $36.0 \mathrm{~km}$ to $41.0 \mathrm{~km}$ & 5.0 & 7.0 \\
\hline & & NH-24-07 & Km Stone Delhi $41.0 \mathrm{~km}$ to $46.0 \mathrm{~km}$ & 5.0 & 7.0 \\
\hline & & NH-24-08 & Km Stone Delhi $46.0 \mathrm{~km}$ to $51.0 \mathrm{~km}$ & 5.0 & 7.0 \\
\hline
\end{tabular}


levels. Since pavements deteriorate with time, it is necessary to maintain/rehabilitate them to provide minimum desired service to its user and save the valuable assets. In India, the current maintenance norms for roads (MORT\&H, 2004) provide scheduled type of $M \& R$ strategies, uniformly across the country. Overlays of varying types and thickness, depending upon the traffic intensity in terms of commercial vehicles per day (CVPD), are scheduled to be provided over a fixed period of $3 / 4$ years. But this may not result into a rational maintenance strategy as the traffic volumes and road use patterns keep on changing very fast. The Indian guidelines on pavements maintenance have suggested intervention criteria for primary, secondary and urban roads. Since the selected highway sections belong to primary roads category, the suggested serviceability levels and the limiting levels of surface defects based on measurement of roughness, cracking, rutting etc. are given in Table 3.

\section{Highway Development and Management (HDM-4)}

The HDM-4, developed by the World Bank, was used for over two decades to combine technical and economic appraisals of road projects, to prepare road investment programmes and to analyse road network strategies. The various versions of the models have been widely used in a number of countries, and have been instrumental in justifying increased road maintenance and rehabilitation budgets in many countries. The models have been used to investigate the economic viability of road projects in over 100 countries and to optimise economic benefits to road users under different levels of expenditures. As such, they provide advanced road investment analysis tools with broad-based applicability in diverse climates and conditions. A Project analysis component of HDM-4 usually involves a small number of road links or sections and the result of economic analysis would provide adequate information for decision making (Kerali et al., 2006).

\section{Optimum Maintenance and Rehabilitation Strategy Analysis}

\subsection{Input Data}

Input data for the study are defined as the 'Multilane Highway Network' and 'Multilane Vehicle Fleet' database files which include various parameters as defined in Table 4 .

\section{Table 3}

Intervention Levels for Primary Roads

\begin{tabular}{|c|c|c|c|c|}
\hline S.No. & $\begin{array}{c}\text { Serviceability } \\
\text { Indicator }\end{array}$ & Level 1 (Good) & Level 2 (Average) & Level 3 (Acceptable) \\
\hline 1 & $\begin{array}{c}\text { Roughness by B.I } \\
(\text { max permissible) }\end{array}$ & $2000 \mathrm{~mm} / \mathrm{km}$ & $3000 \mathrm{~mm} / \mathrm{km}$ & $4000 \mathrm{~mm} / \mathrm{km}$ \\
\hline 2 & $\begin{array}{c}\text { Potholes per km (max } \\
\text { number) }\end{array}$ & Nil & $2-3$ & $4-8$ \\
\hline 3 & $\begin{array}{c}\text { Cracking and } \\
\text { patching area (max } \\
\text { permissible) }\end{array}$ & $5 \%$ & $10 \%$ & $10 \%$ \\
\hline 4 & $\begin{array}{c}\text { Rutting - 20 mm } \\
\text { (max permissible) }\end{array}$ & $5 \mathrm{~mm}$ & $5-10 \mathrm{~mm}$ & $10-20 \mathrm{~mm}$ \\
\hline 5 & $\begin{array}{c}\text { Skid Number (min } \\
\text { desirable) }\end{array}$ & $50 \mathrm{SN}$ & $40 \mathrm{SN}$ & $35 \mathrm{SN}$ \\
\hline
\end{tabular}

Source: MORT\&H (2004) 


\subsection{Traffic Characteristics}

The priority for the maintenance of the road will not only depend upon the condition of the road but also on traffic volume and some special factor like category of road, importance of the road etc. The total traffic in terms of Annual Average Daily Traffic (AADT), initial composition of various vehicles for the selected pavement sections has been used for the analysis in HDM-4. The annual growth rate of each type of vehicles has been taken from the Road Development Plan Vision: 2021 (MORT\&H, 2001).

\subsection{Functional Evaluation of Pavement}

Functional evaluation is the collection of road data pertinent to surface distress like crack area, pothole area with depth, ravelled area, rut depth, surface roughness. The type and extent of distress developed at the surface were observed, based on visual condition survey. It was also measured in quantitative term. The information on the drainage conditions for the existing side drains was also observed. The riding quality of pavement was measured in terms of roughness for all the 13 sections by duly calibrated towed Fifth Wheel Bump Integrator (FWBI) which is a response type road roughness measurement device. The functional evaluation is carried out in such a manner that data will be suitable for analysis of HDM-4 models in the present study. Fig. 1 shows the working of fifth wheel bump integrator on road while collecting the roughness data.

\section{Table 4}

HDM-4 Input Data

\begin{tabular}{|l|l|}
\hline Input & Description \\
\hline Road network data & Basic road details, geometrics, pavement history, pavement condition, etc. \\
\hline Vehicle fleet data & Basic characteristics of vehicle fleet, economical and financial costs, etc. \\
\hline Work standards & Specifications for maintenance and improvement works \\
\hline
\end{tabular}

Source: Kerali et al. (2006)

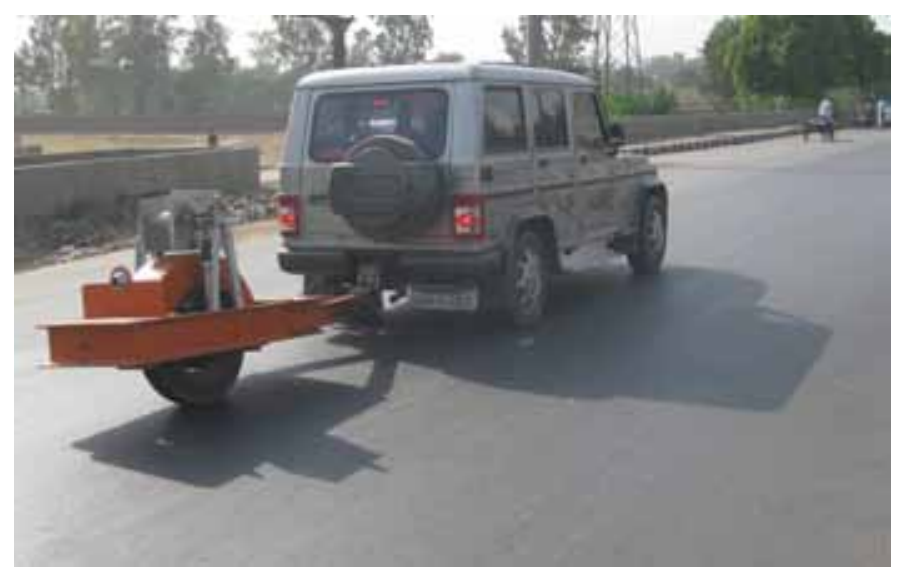

Fig. 1.

A View of Fifth Wheel Bump Integrator Measuring Surface Roughness 


\subsection{Other Factors}

There are number of factors which influence the performance of roads. The important distress factors like ravelling, potholes, rutting, cracks and patching have been considered. Details of different technical factors considered are shown in Table 5.

\subsection{Structural Evaluation by Benkelman Beam Deflection Method}

The magnitude of pavement rebound deflection is an indicator of the ability of the pavement to withstand traffic loading. Higher the rebound deflection, poor is the structural capacity and performance. To assess the structural condition of 13 sections selected for detailed investigations, Benkelman Beam rebound deflection method has been used which is a non destructive method. The deflection measurements were taken as per the procedure laid down in IRC-81 (1997). Fig. 2 shows the deflection studies with the help of Benkelman Beam on National Highway 58.

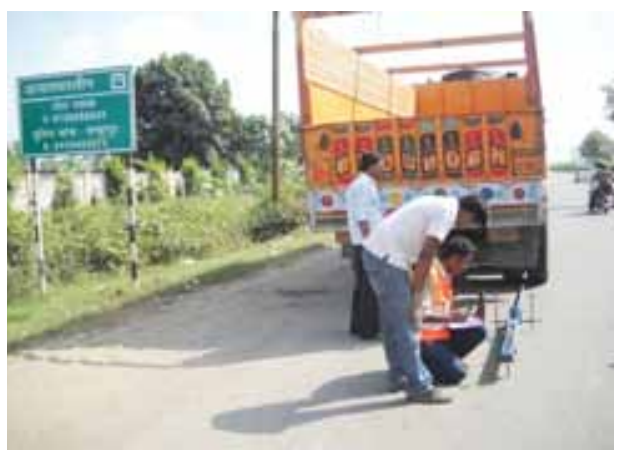

Fig. 2.

Benkelman Beam Studies on NH-24

\section{M\&R Alternative Adopted for Analysis}

The following five $M \& R$ alternatives defined in Table 6 are considered in this study. The first alternative includes the basic routine maintenance for crack, pothole and ravel patching. It is considered as the Base Alternative/ Routine Maintenance for the analysis. Other alternatives include Resealing with $25 \mathrm{~mm}$ Semi Dense Bituminous Concrete (SDBC),

Table 5

Factor Considered for Evaluation

\begin{tabular}{|c|l|l|}
\hline S.No. & Factors & Reasons \\
\hline 1 & Ravelling & $\begin{array}{l}\text { This is the first sign of deterioration of road surface and if tackled } \\
\text { at right time the road can be maintained in good condition with } \\
\text { minimum cost. }\end{array}$ \\
\hline 2 & Potholes & Isolated depressions cause extreme discomfort to the passengers. \\
\hline 3 & Cracks & $\begin{array}{l}\text { The second stage of deterioration of pavement. } \\
\text { Surface which if not addressed leads to pot holes. }\end{array}$ \\
\hline 4 & Rutting & $\begin{array}{l}\text { Causes structural collapse of the pavement and causes discomfort to } \\
\text { the passengers and limits the speed of movement. }\end{array}$ \\
\hline 5 & Patching & $\begin{array}{l}\text { Causes little undulation and also gives a very unpleasant look to the } \\
\text { road surface. }\end{array}$ \\
\hline
\end{tabular}


Overlay of $40 \mathrm{~mm}$ Bituminous Concrete (BC), Resealing with overlay of $40 \mathrm{~mm} \mathrm{BC}$ over that $25 \mathrm{~mm} \mathrm{SDBC}$ and the last alternative is Strengthening with overlay of $\mathrm{BC} 40 \mathrm{~mm}$ upon Dense Bituminous Macadam (DBM) of $50 \mathrm{~mm}$ thickness. SDBC mixes which are neither dense graded nor open graded contain the so-called "pessimum" voids when constructed. The BC can be used for wearing and profile corrective courses. The DBM is specified for use as a base course and/or binder course. The serviceability level considered for this study is Level 1 (Good) as the selected highways sections belong to highest serviceability level of the pavement groups. The intervention criteria's for various alternatives are selected accordingly.

\section{Optimization of Pavement Maintenance Options}

One of main objectives for long-term pavement management is to find the optimal number of maintenance treatments and the best timings and intensities thereof to maintain a given road section during a predefined analysis period $T$. A maintenance option is defined as a set of $k$ maintenance treatments of different intensities $w_{1}, w_{2}, \ldots, w_{k}$ applied at different timings $t_{1}, t_{2}$, ..., $t_{k}$, respectively, over a predefined analysis period $T$. When a maintenance option consists of only overlays, the maintenance intensity may be represented by thicknesses. If various treatment works are considered, the intensity may be represented by a common denominator such as unit cost, incremental pavement strength, etc. In the HDM-4, maintenance options are specified as either scheduled or condition responsive. Scheduled options are specified in the same manner as defined here. Condition-responsive ones are specified by the threshold values of pavement condition indices such as roughness values $r_{1}, r_{2}, \ldots, r_{k}$ at which maintenance works are applied in the simulation of pavement deterioration, and their intensities $w_{1}, w_{2}, \ldots, w_{k}$. Since each threshold value of a condition-responsive work corresponds to specific application timing, however, there always exists an equivalent scheduled option

\section{Table 6}

Proposed $M \& R$ Alternative

\begin{tabular}{|c|c|c|c|c|}
\hline S.No. & Alternatives & Work Standard & Description of Work & $\begin{array}{c}\text { Intervention } \\
\text { Criteria }\end{array}$ \\
\hline \multirow{4}{*}{1} & \multirow{4}{*}{$\begin{array}{c}\text { Routine } \\
\text { Maintenance }\end{array}$} & \multirow{4}{*}{$\begin{array}{c}\text { Routine } \\
\text { Maintenance }\end{array}$} & Crack Repairs & $>5 \%$ \\
\hline & & & Ravel Patching & $>10 \%$ \\
\hline & & & Pothole Patching & $\geq 5 \%$ \\
\hline & & & Shoulder Repair & Structural crack $\geq 5 \%$ \\
\hline 2 & Alternative 1 & Resealing SDBC & Resealing with $25 \mathrm{~mm}$ SDBC & Damage Area $\geq 5 \%$ \\
\hline 3 & Alternative 2 & Thick Overlay & Overlay of $40 \mathrm{~mm} \mathrm{BC}$ & $\mathrm{IRI} \geq 2.8 \mathrm{~m} / \mathrm{km}$ \\
\hline 4 & Alternative 3 & $\begin{array}{c}\text { Resealing and } \\
\text { Overlay }\end{array}$ & $25 \mathrm{~mm}$ SDBC Reseal + Overlay of $40 \mathrm{~mm} \mathrm{BC}$ & $\mathrm{IRI} \geq 2.8 \mathrm{~m} / \mathrm{km}$ \\
\hline 5 & Alternative 4 & Strengthening & Overlay of $40 \mathrm{~mm} \mathrm{BC}+$ DBM $50 \mathrm{~mm}$ & $\mathrm{IRI} \geq 2.8 \mathrm{~m} / \mathrm{km}$ \\
\hline
\end{tabular}


corresponding to any condition-responsive option. The optimization problem of pavement maintenance options is either the maximization or minimization of an objective function $f\left(k ; t_{1}, t_{2}, \ldots, t_{k} ; w_{1}, w_{2}, \ldots, w_{k}\right)$, depending on the specification of the objective function.

\subsection{Selection of Optimum M\&R Strategy}

With so many sections competing for the same funding, it is especially important to optimize the pavement rehabilitation programmes to allow for funding (Bermanian et al., 2005). A project analysis component of HDM-4 is run with a discount rate of $12 \%$. While running the analysis, alternatives 1 to 3 are compared against the base alternative, and the pavement deterioration and $M \& R$ works reports are generated. The economic analysis summary for both Noida-Greater Noida Expressway and $\mathrm{NH}-24$ sections are given in Table 7 and Table 8 respectively. On the basis of the economic analysis summary, the alternative 3 has been selected as the optimum M\&R strategy, having the maximum NPV/Cost among other alternatives. While for $\mathrm{NH}$ 24 sections, alternative 2 is optimum $M \& R$ strategy with maximum NPV/Cost value.

\section{Conclusion}

Our overall objective of this paper is to tackle the lack of innovative techniques and to support decision-making on optimal strategies

\section{Table 7}

Economic Analysis Summary for Expressway Section

\begin{tabular}{|c|c|c|c|c|c|}
\hline Section ID & Base Alternative & Alternative 1 & Alternative 2 & Alternative 3 & Alternative 4 \\
\hline & NPV/CAP & NPV/CAP & NPV/CAP & NPV/CAP & NPV/CAP \\
\hline NGN1 & 0 & 6.408 & 7.799 & 10.269 & 4.851 \\
\hline NGN2 & 0 & 6.900 & 7.709 & 10.128 & 4.727 \\
\hline NGN3 & 0 & 8.058 & 9.633 & 11.924 & 5.735 \\
\hline NGN4 & 0 & 2.462 & 3.206 & 4.491 & 1.954 \\
\hline NGN5 & 0 & 7.230 & 8.292 & 10.560 & 4.922 \\
\hline
\end{tabular}

Note: NPV is denoted for Net Present Value; CAP is denoted for Capital Cost

Table 8

Economic Analysis Summary for $\mathrm{NH}-24$

\begin{tabular}{|c|c|c|c|c|c|}
\hline Section ID & Base Alternative & Alternative 1 & Alternative 2 & Alternative 3 & Alternative 4 \\
\hline & NPV/CAP & NPV/CAP & NPV/CAP & NPV/CAP & NPV/CAP \\
\hline NH-24-01 & 0 & 8.194 & 12.437 & 11.919 & 8.311 \\
\hline NH-24-02 & 0 & 9.368 & 14.198 & 13.502 & 9.379 \\
\hline NH-24-03 & 0 & 10.434 & 15.615 & 14.838 & 10.308 \\
\hline NH-24-04 & 0 & 9.465 & 14.302 & 13.591 & 9.434 \\
\hline NH-24-05 & 0 & 7.408 & 11.292 & 10.870 & 7.606 \\
\hline NH-24-06 & 0 & 10.787 & 16.139 & 15.240 & 10.517 \\
\hline NH-24-07 & 0 & 12.879 & 19.127 & 18.013 & 12.422 \\
\hline NH-24-08 & 0 & 7.003 & 10.730 & 10.366 & 7.278 \\
\hline
\end{tabular}


of investment and preservation for road infrastructure. HDM-4 has emerged as a very powerful tool for developing various aspects of pavement maintenance management system such as predicting the pavement deterioration, programming of maintenance and rehabilitation works, carrying out lifecycle cost analysis and cost optimization. Using 'Project Analysis' component of HDM-4, the optimum M\&R strategy for the various highway sections have been determined on the basis of NPV/CAP value. In this paper, optimum maintenance and rehabilitation strategy was obtained on the basis of maximum NPV/ $\mathrm{CAP}$ value, which shows the section having maximum NPV/CAPvalue would be maintained on priority basis as compared to the other sections and so on. Similarly out of all five alternatives preferred, the alternative with higher NPV/ $\mathrm{CAP}$ value is considered as the best alternative for that particular road section. In the present study, alternative 3 was considered to be the best alternative for Noida-Greater Noida Expressway section and alternative 2 was considered best for $\mathrm{NH}-24$ road sections. Finally, a comprehensive procedure was presented as a practical guideline to assist road agencies.

\section{References}

Abaza, K.A. 2002. An optimum flexible pavement lifecycle analysis model, Journal of Transportation Engineering. DOI: http://dx.doi.org/10.1061/(ASCE)0733947X(2002)128:6(542), 128(6): 542-549.

Abaza, K.A.; Abu-Eisheh, S.A. 2003. An optimum design approach for flexible pavements, International Journal of Pavement Engineering. DOI: http://dx.doi.org/10.1080/ 1029843031000087464, 4(1): 1-11.

Bermanian, S.; Polish, P.; Maurer, G. 2005. Pavement Management System based on Financial Consequence, Transportation Research Record: Journal of the Transportation Research Board. DOI: http://dx.doi. org/10.3141/1940-04, 1940: 32-37.

Deshpande, V.P.; Damnjanovic, I.; Gardoni, P. 2008. Modeling the effects of rehabilitation actions on the reliability of flexible pavements, Transportation Research Board 87th Annual Meeting, Washington DC, USA.

Fwa, T.F.; Sinha, K.C. 1991. Impact of Pavement Performance Consideration on Economic Evaluation of Pavement Strategies, Transportation Research Record: Journal of the Transportation Research Board, 1305: 215223.

Indian Roads Congress, IRC-81. 1997. Guidelines for Strengthening of Flexible Road Pavements using Benkelman Beam Deflection Technique, IRC, New Delhi.

Jain, K.; Jain, S.S.; Chauhan, M.P.S. 2011. Development of a Decision Tree for Maintenance Treatment Selection at Network Level. In Proceedings of the 1st Conference of Transportation Research Group of India (CTRG), Bangalore, India.

Jain, S.S.; Gupta, A.K.; Khanna, S.K.; Dayanand. 1996. Development of Maintenance and Rehabilitation investment strategy for Flexible Pavements, Journal of Indian Roads Congress, 57(2): 368-418. 
Kerali, H.G.R.; Odoki, J.B.; Stannard, E.E. 2006. Overview of HDM-4, HDM-4 Documentation Series, Volume 1, The World Road Association (PIARC), Paris, France.

Mamlouk, M.S.; Zaniewski, J.P.; He, W. 2000. Analysis and design optimization of flexible pavement, Journal of Transportation Engineering. DOI: http://dx.doi. org/10.1061/(ASCE)0733-947X(2000)126:2(161), 126(2): 161-167.

MORT\&H. 2001. Road Development Plan Vision: 2021, Ministry of Road Transport and Highways, Government of India, New Delhi.

MORT\&H. 2004. Guidelines for Maintenance of Primary, Secondary and Urban Roads, Ministry of Road Transport and Highways, Government of India, New Delhi.

MORT\&H. 2010. Basic Road Statistics of India, Ministry of Road Transport and Highways, Government of India, New Delhi.

MORT\&H. 2012. Annual Report 2011-2012, Ministry of Road Transport and Highways, Government of India, New Delhi.

Sanchez-Silva, M.; Arroyo, O.; Junca, M.; Caro, S.; Caicedo, B. 2005. Reliability based design optimization of asphalt pavements, International Journal of Pavement Engineering. DOI: http://dx.doi.org/10.1080/10298430500445506, 6(4): 281-294.

Shahin, M.Y. 2005. Pavement Management for Airports, Roads, and Parking Lots. $2^{\text {nd }}$ Edition, Springer science and business media, LLC, NY, USA. 